УДК 346.52

DOI https:/ / doi.org/10.32837/yuv.v0i6.2051

А. Топал,

аспірант кафедри господарського права і процесу

Національного університету «Одеська юридична академія»

\title{
ДО ПИТАННЯ ГАРАНТІЙ У РАЗІ ЗДІЙСНЕННЯ ІНВЕСТУВАННЯ У СФЕРІ ДЕРЖАВНО-ПРИВАТНОГО ПАРТНЕРСТВА
}

Постановка проблеми. Інфраструктура будь-якої країни має вирішальне значення для економічного зростання, соціальної стабільності та високого рівня розвитку у світовому просторі. Особливу роль у реалізації інфраструктурних проектів відіграє державно-приватне партнерство (далі - ДПП), що дає змогу залучити інвестиції. Впровадження ДПП у різноманітні сфери робить його універсальним механізмом для розв'язання довготермінових проєктів на шляху реалізації соціальних та інфраструктурних проєктів, які мають публічний інтерес та загальнодержавне значення.

ДПП відкриває Україну компаніям зі світовим ім'ям, новими технологіями та фінансовими ресурсами, так, для прикладу, у сфері інфраструктури морських портів з'явилися такі компанії, як DP World (порт «Південний»), QTerminals (порт «Ольвія») і «Рісоїл-Херсон» (порт «Херсон»). Крім того, за рейтингом інвестиційних проєктів, проведених Delo.ua, визначено 10 інвестиційних проєктів у морські порти, які можуть залучити в економіку України майже 1 мільярд доларів, основна частка - це проєкти державно-приватного партнерства. На першому місці знаходяться концесії морського порту «Ольвія» і Херсонський морський порт на суму \$ 672,7 млн. Нині концесія портів «Ольвія» і «Херсон» розпочата, що $€$ новим етапом у розвитку інфраструктури морських портів України з використанням механізмів ДПП [1].
Переваги та важливість концесії як форми реалізації ДПП зрозумілі $з$ огляду на суми інвестицій. Для порту «Ольвія» загальна сума інвестицій за 35 років концесії становитиме 17,3 млрд грн, а для порту «Херсон» - 300 млн грн.

При цьому, незважаючи на взаємні вигоди різних форм державно-приватного партнерства, вони мають істотні ризики, в першу чергу для приватного партнера як сторони вразливішої, оскільки реалізація проєктів ДПП залежить від політики концедента (держави) як сторони договору. Загалом це впливає на надходження інвестицій в об'єкти ДПП та вимагає від держави надійної системи гарантій захисту інвестицій.

У законодавстві України гарантіï захисту в процесі інвестування у сфері ДПП закріплені в різних законах: «Про державно-приватне партнерство», «Про інвестиційну діяльність», «Про режим іноземного інвестування», «Про оренду державного та комунального майна», «Про концесії, «Про приватизацію державного та комунального майна», «Про морські порти України» та інших.

Хоча протягом останніх років було запроваджено деякі новації в правове регулювання розвитку ДПП, із прийняттям нових законів «Про концесії та «Про оренду державного та комунального майна» було забезпечено більш прозору і спрощену процедуру передачу об'єктів державної власності приватним партнерам, але нині 
в Україні не сформовані механізми, які могли б забезпечити реальні гарантії захисту інвестицій, у тому числі у сфері ДПП. При цьому гарантії інвестицій в Україні залишаються поняттями на «папері», які потрібно оцінювати предметно в кожному окремому випадку залежно від можливості іх використання.

Стан опрацювання проблематики. Питанням державно-приватного партнерства займались такі вчені, як М. Авксентьєв, О. Вінник, О. Вишнякова, О. Сирота, К. Павлюк, С. Павлюк, О. Сиротюк, С. Терещенко, Д. Шликов та інші. Також варто зазначити, що питанням гарантій у процесі інвестування у сфері ДПП присвячені роботи О. Гофмана, Г. Будурової, Ю. Коваль, М. Кочеров, О. Огій та інших.

Метою статті - проаналізувати зміст правових гарантій у процесі інвестування у сфері державно-приватного партнерства та визначити напрями вдосконалення застосування правових гарантій для забезпечення захисту прав приватних інвесторів.

Виклад основного матеріалу. Закон України «Про державноприватне партнерство» № 2404-VI від 01.07.2010 р. (далі - Закон ДПП) $€$ основним нормативно-правовим актом, що регулює відносини у сфері державно-приватного партнерства та визначає основні організаційно-правові засади взаємодіі державного та приватного секторів під час здійснення інвестування, а також закріплює основні принципи регулювання державно-приватного партнерства на договірній основі [2].

ДПП відповідно до Закону ДПП це співробітництво між державним партнером та приватним партнером, що здійснюється на основі договору та відповідає ознакам державноприватного партнерства.

У цьому разі характерною особливістю співробітництва між державним партнером та приватним $€$ інвестування в довгостроковий проєкт із роз- поділом ризиків між партнерами. При цьому Законом про ДПП при реалізації проєктів ДПП встановлюються показники результативності - це кількісні та якісні показники щодо надійності та доступності об'єкта державно-приватного партнерства, що мають бути досягнуті в результаті реалізації проєкту, що здійснюється на умовах державно-приватного партнерства, з урахуванням його мети та завдань.

Водночас для приватного партнера наявність ризику узгоджується 3 принципами ведення підприємництва, а у сфері ДПП компенсується встановленими державою гарантіями.

У наукових працях $є$ різні підходи до визначення поняття гарантій, що пов'язано як із правовим статусом суб'єктів права, так і з видом діяльності. При цьому залежно від виду відносин визначається зміст поняття. Наприклад, це можуть бути державні, банківські, фінансові, страхові, правові, соціальні, гарантійний лист, гарантія (гарантійний термін) на товар та інше.

Водночас для будь-якого проєкту ДПП перевага залишається за гарантіями з боку держави. Фактично гарантії з боку держави в проєктах ДПП стають певними критеріями для захищеності інтересів прав інвесторів та якісним показником зацікавленості держави в залученні інвесторів.

Аналізуючи чинне законодавство України, можна зробити висновок про певну неузгодженість щодо поняття «гарантії у процесі інвестування в межах проєктів ДПП.

Так, у Законі України «Про інвестиційну діяльність» міститься поняття «державних» гарантій захисту інвестицій як системи правових норм, які спрямовані на захист інвестицій та не стосуються питань фінансово-господарської діяльності учасників інвестиційної діяльності та сплати ними податків, зборів (обов'язкових платежів). Цим Законом встановлений ключовий принцип: державні гарантії захисту інвестицій не можуть бути 
скасовані або звужені стосовно інвестицій, здійснених у період дії цих гарантій [3].

Далі в ст. 18 Закону України «Про державно-приватне партнерство» встановлено, що державна підтримка здійснення державно-приватного партнерства може надаватися шляхом надання «державних» гарантій та «місцевих» гарантій. Очевидно, що у контексті цього Закону йдеться про «державні (місцеві)» гарантії як один із способів забезпечення виконання зобов'язань, що передбачене цивільним, господарським законодавством, але може бути реалізоване через бюджетне законодавство.

Зокрема, відповідно до положень ч. 3 ст. 17 Бюджетного кодексу України правочин щодо надання державної (місцевої) гарантії оформляється в письмовій формі та має визначати предмет гарантії, повні найменування та місцезнаходження суб'єкта господарювання і кредитора (у разі гарантування виконання зобов'язань за кредитним договором), обсяг кредиту (позики), обсяг гарантійних зобов'язань та порядок їх виконання, права та обов'язки гаранта і кредитора, умови настання гарантійного випадку, строк дії гарантії. При цьому державні (місцеві) гарантії надаються на умовах платності, строковості, а також забезпечення виконання зобов'язань у спосіб, передбачений законом. Водночас відповідно до положень ч. 1 цієї норми державні гарантії для забезпечення повного або часткового виконання боргових зобов'язань суб'єктів господарювання - резидентів України можуть надаватися за рішенням Кабінету Міністрів України [4].

Водночас, на думку науковців О. Гофмана, Г. Будурової, державна гарантія виступає засобом підтримки суб'єктів господарювання (приватних партнерів - резидентів України), що реалізують проєкт ДПП, а також виступає засобом забезпечення виконання господарських кредитних зобов'язань приватного партнера перед кредитором, що надав кредитний ресурс [5, с. 111].

Таким чином, чинне законодавство України містить певну термінологічну неузгодженість у поняттях «державної» гарантії, що потребує додаткового правого аналізу, але в площині досліджуваного питання розглянемо саме правові гарантії, що закріплені в законах України «Про інвестиційну діяльність» та «Про державно-приватне партнерство».

Науковці 3 різних галузей права досліджували поняття гарантій. Так, у Великому енциклопедичному юридичному словнику поняття «гарантіï (франц. garantie - забезпечення, порука) охоплює всю сукупність об'єктивних і суб'єктивних чинників, спрямованих на практичну реалізацію прав і свобод, на усунення можливих перешкод їх повного або належного здійснення. Держава, яка закріплює права та свободи особи в законодавстві, бере на себе певні зобов'язання зі створення сприятливих умов для ефективного забезпечення останніх. Розрізняють чотири види гарантій: економічні, політичні, ідеологічні та юридичні. Неухильне дотримання гарантій прав і свобод людини та громадянина $€$ однією з умов розвитку демократії, законності, прогресу в усіх сферах суспільного життя [6, с. 555].

Л. Крупа під гарантіями розуміє підкріплену силою держави систему юридичних засобів та умов, що посилюють права уповноважених суб'єктів і обов'язки зобов'язаних суб'єктів правовідносин, що забезпечують їх реалізацію за допомогою особливої процедури (деталізація регулювання, надання регулюванню більшої юридичної сили) [7, с. 117].

У сфері ДПП О. Огій під гарантіями у ДПП розуміє систему правових та інституційних способів і засобів, що забезпечують належне визнання, реалізацію прав та обов'язків сторін ДПП та їх правовий захист [8, c. 117].

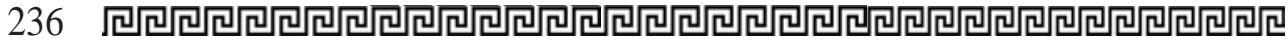




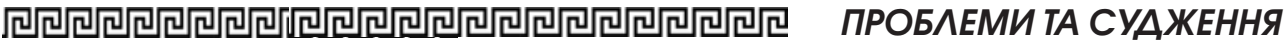

Законодавством України гарантіï у сфері ДПП зводяться до забезпечення умов здійснення діяльності та захисту прав суб'єктів. Так, ст. 20 Закону України «Про державно-приватне партнерство» передбачено, що держава гарантує додержання встановлених законодавством України умов для провадження діяльності приватних партнерів, пов'язаної 3 виконанням договорів, укладених у рамках державно-приватного партнерства, додержання прав і законних інтересів приватних партнерів.

До прав і обов'язків сторін, визначених договором, укладеним у рамках державно-приватного партнерства, протягом строку його дії застосовується законодавство України, чинне на день його укладення. Зазначені гарантії поширюються на зміни цивільного і господарського законодавства, що регулює майнові права та обов'язки сторін, і не стосуються змін законодавства 3 питань оборони, національної безпеки, забезпечення громадського порядку, охорони довкілля, стандартів якості товарів (робіт, послуг), податкового, валютного, митного законодавства, законодавства 3 питань ліцензування та іншого законодавства, що регулює правовідносини, в яких не діють принципи рівності сторін (державного та приватного партнерів) [2].

Схожі положення закріплені в ст. 18 Закону України «Про інвестиційну діяльність», так, держава гарантує стабільність умов здійснення інвестиційної діяльності, додержання прав і законних інтересів іï суб'єктів. При цьому умови договорів, укладених між суб'єктами інвестиційної діяльності, зберігають свою чинність на весь строк діi цих договорів і у випадках, коли після їх укладення законодавством (крім податкового, митного та валютного законодавства, а також законодавства $з$ питань ліцензування певних видів господарської діяльності) встановлено умови, що погіршують становище суб'єктів або обмежують їхні права, якщо вони не дійшли згоди про зміну умов договору [3].

Отже, правові гарантії являють собою певне коло норм, закріплених у різних нормативно-правових актах, спрямованих на закріплення умов здійснення інвестування (господарювання) у сфері ДПП, визнання прав та обов'язків сторін договору ДПП та їх захисту.

Загалом, як зазначає Ю. Коваль, система гарантій захисту інвестицій у проєктах ДПП представлена багаторівневою структурою, яка об'єднує сукупність загальних та спеціальних інвестиційних гарантій. Ця система має багаторівневу структуру, і до іï складу входять такі елементи: міжнародний рівень гарантування інвестицій, конституційний рівень, загальне та спеціальне інвестиційне законодавство у галузі ДПП, а також інші гарантіiі, які не можна за своєю суттю зарахувати до якого-небудь з перелічених вище елементів. Водночас, на думку автора, наявність значної кількості присвячених гарантуванню інвестицій норм, структурованих у межах багаторівневої системи, не призвела ані до збільшення ефективності надаваних гарантій, ані до підвищення якості інвестиційного законодавства, яке стало більш заплутаним та складним для розуміння потенційного інвестора, а тим більше - іноземного [9].

Крім того, на думку, M. Кочерова, новий Закон ДПП дещо ускладнив життя концесіонера. Зокрема, в Законі про ДПП зазначається, що на подібні гарантії не поширюються зміни законодавства щодо питань оборони, національної безпеки, забезпечення громадського порядку та охорони довкілля, ліцензування, правил та умов надання суспільно значущих послуг на ринках у стані природних монополій. Раніше не було такого застереження [10].

Виходячи 3 системного аналізу чинного законодавства, правові гарантії захисту інвестицій можна поділити на гарантії від зміни законодавства, 
гарантії від примусових вилучень, а також незаконних дій державних органів та їх посадових осіб, компенсації і відшкодування збитків інвесторам, гарантії в разі припинення інвестиційної діяльності, гарантії переказу доходів, прибутків та інших сум у зв'язку з іноземними інвестиціями.

Щодо гарантій у процесі інвестування у сфері ДПП, то з огляду на системний аналіз чинного законодавства їх можна поділити на гарантії недискримінації приватних інвесторів та невтручання в їхню господарську діяльність, гарантії інвестування, пов'язані 3 компенсацією внесених інвестицій та компенсації збитків експропріації (примусове (без відшкодування чи оплачуване) позбавлення власності), гарантії «стабільності» законодавства, гарантії інвестування, які передбачають незалежне вирішення спорів, гарантії переказу капіталу.

Водночас аналіз практики реалізації ДПП доводить, що гарантії у процесі інвестування у сфері ДПП $€$ загальними та декларативними i майже не передбачають специфіки проєктів ДПП. Зокрема, спроба змінити декларативність державних гарантій у рамках ДПП була вжита Проєктом Закону «Про внесення змін до Бюджетного кодексу України щодо створення умов для модернізації інфраструктури шляхом реалізації проектів на умовах державно-приватного партнерства, у тому числі концесії» (реєстр. № 8126 від 15.03.2018 р.).

$\mathrm{y}$ цьому випадку одним 3 обгрунтувань, відповідно до Пояснювальної записки щодо прийняття проєкту Закону, будо те, що у разі надання державних гарантій у рамках здійснення ДПП виникає зовсім інша ситуація. Тут держава (державний партнер) як сторона договору, укладеного в рамках ДПП, надає державну гарантію як підтвердження виконання своїх зобов'язань за відповідним договором. Виплати приватному партнеру або кредиторам за такою гарантію виникають лише за умов невиконання державним партнером зобов'язань, зумовлених договором, укладеним у рамках ДПП, або в разі настання ризиків, відповідальність за які відповідно до договору, укладеного в рамках ДПП, покладені на державного партнера. За таких умов у разі настання гарантійного випадку за державною гарантією, наданою в рамках ДПП, відповідальність має нести держава (державний партнер), а не приватний партнер.

При цьому метою проєкту Закону є запровадження в Україні міжнародновизнаних підходів щодо врегулювання фінансових питань, у тому числі надання державної підтримки здійснення ДПП, зокрема визначення бюджетних механізмів застосування державних (місцевих) гарантій для реалізації проєктів на умовах ДПП, у тому числі концесіі, а також врегулювання умов та механізму взяття державними партнерами довгострокових зобов'язань за договорами, укладеними в рамках ДПП, в одній із форм, передбачених Законом України «Про державно-приватне партнерство» [11].

На жаль, проект було відкликано 29.08.2019 р. та механізми реалізаціï гарантій у процесі інвестування у сфері ДПП потребують подальшого розроблення та втілення в життя.

Отже, з огляду на публічний інтерес розвитку ДПП та аналіз нормативно-правових актів у сфері ДПП можна зробити висновок, що встановлені правові гарантії інвестування сфері ДПП спрямовані на визнання та захист прав і інтересів інвесторів, але $є$ необхідность усунення термінологічної плутанини та систематизації понять «державна підтримка», «державні гарантії та «державні гарантіі захисту інвестицій» та створення правових механізмів їх реалізації.

Проаналізовано зміст правових гарантій у процесі інвестування у сфері державно-приватного партнерства. Зазначено, характерною 
особливістю ДПП як співробітниитва між державним партнером та приватним є інвестування в довгостроковий проєкт із розподіленням ризиків між партнерами $з$ наявністю показників результативності - це кількісні та якісні показники щодо надійності та доступності об'єкта державно-приватного партнерства, що мають бути досягнуті в результаті реалізації проєкту, щзо здійснюється на умовах державно-приватного партнерства, з урахуванням його мети та завдань.

Обгрунтовано, що, незважаючи на взаємні вигоди різних форм державно-приватного партнерства, вони мають істотні ризики, в першу чергу для приватного партнер як сторони вразливішої, оскільки реалізація проєктів ДПП залежить від політики концедента (держави) як сторони договору.

Загалом ие впливае на надходження інвестииій в об'єкти ДПП та вимагає від держави системи гарантій захисту інвестицій. Теорія та практика різноманітних сфер, моделей та інструментів державно-приватного партнерства інвестування підтверджуе необхідність встановлення гарантій для інвесторів для захисту власних капіталовкладень. Системний аналіз цих законів доводить, що гарантї в процесі інвестування у сфері ДПП є загальними та декларативними $i$ майже не передбачають специфіки проєктів ДПП.

Проаналізовано спеціальне законодавство у сфері ДПП, зроблено аналіз, що правові гарантіі спрямовані на захист інвестицій та являють собою систему правових норм різних нормативно-правових актів. Визначено, що напрями вдосконалення застосування правових гарантій для забезпечення захисту прав приватних інвесторів, зокрема щодо усунення термінологічної плутанини та систематизаціі понять «державна підтримка», «державні гарантї̈ та «державні гарантї захисту інвестицій» та створення правових механізмів їх реалізаціï.

Ключові слова: державно-приватне партнерство, гарантіі, правові гарантії, інвестиції.

\section{Topal A. On the issue of guarantees when investing in the field of public-private partnership \\ The content of legal guarantees} when investing in the field of publicprivate partnership is analyzed. It is noted that a characteristic feature of PPP as cooperation between public and private partners is investing in a long-term project with risk sharing between partners with the availability of performance indicators - these are quantitative and qualitative indicators of reliability and accessibility of public-private partnership, which must be achieved implementation of the project, which is carried out on the terms of public-private partnership, taking into account its purpose and objectives.

It is justified that despite the mutual benefits of various forms of public-private partnership, they have significant risks, especially for the private partner as a more vulnerable party, as the implementation of PPP projects depends on the policy of the grantor (state) as a party.

In general, this affects the inflow of investment in PPP facilities and requires the state to guarantee investment protection. The theory and practice of various areas, models and tools of public-private investment partnership, confirms the need to establish guarantees for investors to protect their investments. A systematic analysis of these laws proves that guarantees for investing in the field of PPP are general and declarative and almost do not provide for the specifics of PPP projects. 
The special legislation in the field of $P P P$ is analyzed, the analysis is made that legal guarantees are directed on protection of investments and represent system of legal norms of various regulatory legal acts. The directions of improvement of application of legal guarantees for maintenance of protection of the rights of private investors are defined. In particular, on the elimination of terminological confusion and systematization of the concepts of "state support", "state guarantees" and "state guarantees of investment protection" and the creation of legal mechanisms for their implementation.

Key words: public-private partnership, guarantees, legal guarantees, investments.

\section{Література}

1. Delo.ua. URL: https://delo.ua/ business / top-10-investicij-v-portovujuotrasl-ukrainy-351354/ (дата звернення 14.12.2020).

2. Про державно-приватно партнерство : Закон України № 2404-VI вid 01.07.2010 p. URL: https://zakon. rada.gov.ua/laws /show /2404-17/ conv\#n260 (дата звернення 14.12.2020).

3. Про інвестиційну діяльність : Закон України № 1560-ХІІ від 18 вересня 1991 p. URL: https: / / zakon.rada.gov.ua / laws/show/1560-12/conv\#n262 (dama звернення 14.12.2020).

4. Бюджетний кодекс України № 2456-VI від 8 липня 2010 p. URL: https:// zakon.rada.gov.ua/laws/show/2456-17/ сопџ\#n1827 (дата звернення 14.12.2020).

5. Гофман О.Р., Будурова Г.М. Сучасні перспективи використання інсти- туту державної гарантії в механізмі державно-приватного партнерства. URL: http://pravoisuspilstvo.org.ua/ archive/2019/5_2019/part_1/19.pdf (дата звернення 14.12.2020).

6. Великий енциклопедичний юридичний словник / за ред. акад. НАН України Ю.С. Шемшученка. 2-ге вид., переробл. i допов. Київ : Юридична думка, 2012. $1020 \mathrm{c}$

7. Крупа Л. К вопросу о юридическом содержании понятия «спещиальный правовой режим». Підприємництво, господарство і право. 2001. № 2. С. 12.

8. Огій O.C. Гарантї̈ приватного партнера під час реалізації державноприватного партнерства. Науковии вісник Міжнародного гуманітарного університету. Серія: Юриспруденція. 2014. Bun. 7. C. 116-119. URL: http://nbuv.gov.ua/UJRN/ Nvmgu_jur_2014_7_30 (дата звернення 14.12.2020)

9. Коваль Ю. Інвестиційні гарантії y проектах державно-приватного партнерства. URL: https://jurimex.ua/ua/ publication/inviestitsionnyie-gharantii-vproiektakh-ghosudarstvienno-chastnoghopartnierstua (дата звернення 14.12.2020).

10. Кочеров M. «Нестабільні» гарантіi nрав приватних партнерів. URL: https: / / yur-gazeta.com/publications / practice/ derzhavnoprivatne-partnerstvo/nestabilnigarantiyi-prav-privatnih-partneriv.html (дата звернення 14.12.2020).

11. Проект Закону «Про внесення змін до Бюджетного кодексу України щодо створення умов для модернізації інфраструктури шляхом реалізаціі проектів на умовах державно-приватного партнерства, у тому числі концесї) (реєстр. № 8126 вid 15.03 .2018 p.). URL: http:// w1.c1.rada.gov.ua/pls / zweb2 / webproc4 _2? id $=\& p f 3516=8126 \& s k l=9 \quad($ дата $\quad$ звер нення 14.12.2020). 